\title{
National Preferences and International Institutions: Evidence from European Monetary Integration
}

\author{
James I. WALSh \\ University of North Carolina at Charlotte
}

\begin{abstract}
How do states reach agreement on creating or changing international institutions? The dominant theory of international cooperationinstitutional theory-specifies how states with shared interests use institutions to realize joint gains and to minimize the possibility of defection. But institutional theory has little to say about when states will hold the shared interests that lead them to create international institutions in the first place. I evaluate two general explanations of national preferences regarding international institutions against the record of attempts to institutionalize monetary cooperation in the European Union since the 1970s. Drawing on central insights of the constructivist tradition, idea diffusion theory holds that national preferences converged on those of German decision-makers by the late 1980s and that European governments willingly accepted German terms for monetary union. Recognition that German institutions and policies produced superior economic outcomes drove this change in preferences. A domestic-politics explanation holds that preferences varied because of differences in the structure of the domestic political economy and the political costs of achieving price stability, which was one of Germany's conditions for monetary integration. Lower inflation in the late 1980s reduced these costs enough for French and Italian governments to pursue a monetary union that included Germany. The evidence indicates that idea diffusion had little influence on the development of European monetary institutions. Governments held and advocated distinctly different preferences regarding such institutions from the late 1970s through the mid-1990s. The finding that domestic politics rather than idea diffusion drives national preferences challenges some of the claims of recent constructivist literature in international politics about the importance of communication and ideas in promoting cooperation. In the conclusion I discuss how the findings of this article might be squared with constructivism by paying more attention to domestic politics.
\end{abstract}

How do states reach agreement on creating or changing international institutions? The dominant theory of international cooperation-institutional theoryspecifies how states with shared interests use institutions to realize joint gains

\footnotetext{
Author's note: For their comments and suggestions I thank David Andrews, Elizabeth Bomberg, Philip Cerny, Martin Edwards, Jonathan Golub, C. Randall Henning, Peter Lange, Justin Pearlman, John Peterson, Stephen J. Silvia, James Vreeland, and participants at the annual meeting of the International Studies Association, Washington, D.C., February 1999, and the conference "International Institutions: Global Processes, Domestic Consequences," Duke University, Durham, North Carolina, April 1999.
} 
and to minimize the possibility of defection. But institutional theory has little to say about when states will hold the shared interests that lead them to create international institutions in the first place. I evaluate two general explanations of national preferences regarding international institutions against the record of attempts to institutionalize monetary cooperation in the European Union since the 1970s. Idea diffusion theory focuses on how preferences converge through a process of interstate communication and learning from common experiences. Drawing on central insights of the constructivist tradition, idea diffusion theory holds that the preferences of decision-makers in states of the European Union converged on those of German decision-makers by the late 1980s and that they willingly accepted German terms for monetary union. Recognition that German institutions and policies produced superior economic outcomes drove this change in preferences. A domestic-politics explanation views decision-makers as maximizing their political support by shaping their institutional preferences to accord with the demands of powerful societal groups. In this account national preferences varied because of differences in the structure of the domestic political economy and the political costs of achieving price stability, which was one of Germany's conditions for monetary integration. Lower inflation in the late 1980s reduced these costs enough for French and Italian governments to pursue a monetary union that included Germany.

The fact that both theories expect European monetary institutions to reflect German preferences means that it is impossible to use these institutions as the dependent variable. This problem is not limited to the cases at hand; there are many other cases where states that played important roles in creating international institutions held both a preponderance of bargaining power and persuasive ideas (Ikenberry and Kupchan, 1990). Identifying which causal mechanism is more influential requires analysis of alternative dependent variables for which the theories make divergent predictions. I focus on the process of negotiating changes to the rules of European monetary institutions, arguing that the theories generate different expectations about the conditions under which preferences will converge and about which states will propose changes to existing rules.

The evidence indicates that idea diffusion had a smaller influence on the development of European monetary institutions than did domestic politics. Governments held and advocated distinctly different preferences regarding such institutions from the late 1970s through the mid-1990s. This finding has implications for how we think about the politics of monetary union after the introduction of the single European currency in 1999 and of international cooperation more generally. If states continue to have different preferences regarding the rules of European monetary institutions, the prospects for smooth and successful adaptation of monetary union to economic and political shocks are low. A deep recession might produce interstate conflict over the single monetary policy, which could undermine the independence of the new European Central Bank and limit integration in other areas of economic policy. Thus in contrast to the expectations generated by many central bankers and political leaders in Europe, monetary union may not be characterized by like-minded decision-makers working out technically superior policies within a commonly accepted intellectual and institutional framework.

Comparing the power of explanations that focus on domestic politics and idea diffusion also contributes to our understanding of the sources of international cooperation. The finding that domestic politics rather than idea diffusion drives national preferences challenges some of the claims of recent constructivist literature in international politics about the importance of communication and ideas in promoting cooperation. In the conclusion I discuss how the findings of this article might be squared with constructivism by paying more attention to domestic politics. 
The remainder of the article is divided into five sections. The next reviews in greater detail the idea diffusion and domestic politics explanations of national preferences. I then lay out specific hypotheses derived from each theory and the research design for the empirical sections. The subsequent three sections evaluate these hypotheses in the light of evidence derived from attempts to alter the European Monetary System (EMS) in the 1980s, the negotiation of the 1991 Maastricht Treaty that laid out a detailed plan for monetary union by the end of the decade, and the negotiation in the mid-1990s of new institutions that would facilitate management of the single currency, the Stability Pact and Euro Council. The concluding section summarizes the findings and draws out some implications for future analysis of international cooperation.

\section{National Preferences and International Institutions}

\section{Preferences and Institutions}

Institutional theory holds that states create international institutions to realize joint gains through cooperation. Institutions promote cooperative behavior by increasing the information available about other states' goals, past behavior, and expectations, which makes it easier to detect and punish defection, and by increasing decision-makers' time horizons and trust in each other, which makes them more willing to engage in cooperation that imposes short-term costs but provides long-term gains (Krasner, 1983; Axelrod, 1984; Keohane, 1984; Oye, 1986; Keohane and Martin, 1999). Institutional theory provides a straightforward explanation of why some states in the European Union would agree to pool sovereignty over monetary policy. European monetary institutions promised joint gains in the form of stable exchange rates that reduce the risks to trade and investment, support the single European market and common agricultural policy, and reduce vulnerability to changes in American monetary policy. Monetary integration also anchored Germany more firmly to its western European partners (Andrews, 1993; Commission of the European Communities, 1990; Garrett, 1993; Henning, 1997; McNamara, 1993). Many of the specific rules associated with European monetary institutions were designed to discourage participating states from exploiting their partners' willingness to cooperate. For example, the 1991 Maastricht Treaty's convergence criteria for participation in the single currency provided an ex ante standard against which to evaluate compliance with the goal of price stability, whereas the creation of a single currency in 1999 makes it impossible to defect from the single monetary policy without going through the costly and risky process of reintroducing a national currency. Yet the promise of joint gains and the knowledge that institutions may reduce the possibility of defection are themselves not sufficient conditions for cooperation. As Keohane and Martin (1999:20) put it,

\footnotetext{
[institutional theory] does help us explain state strategies, since those strategies are affected not only by fundamental preferences but by the constraints and opportunities in their environment. . . But [it] does not account for more fundamental preferences over outcomes.... For international relations theory to make really significant progress, it will need to go beyond analysis of institutional strategies to explain variations in state preferences.
}

The evolution of European monetary institutions is a useful illustration of this problem with institutional theory. European governments began serious discussions about creating a single currency and central bank in the late 1960s, but agreement on the precise forms of most of the necessary institutions was delayed until signing of the Maastricht Treaty in 1991 because important states held 
different preferences regarding the specific goals and rules of monetary union (Moravcsik, 1998; McNamara, 1998). Monetary integration proposals advocated the creation of what I term politicized or technocratic rules for European monetary institutions. These proposals emphasized different economic problems and advocated different policies and institutions as solutions. At least until the mid-1980s, French and Italian governments preferred politicized models of European monetary integration that identified the principal economic problems facing governments as slow growth and low employment brought about by insufficient demand and investment. According to this perspective, European monetary institutions should allow governments the discretion to respond to adverse economic developments with active fiscal and monetary policies to promote demand and investment during recessions, for example, by deliberately running budget deficits, reducing interest rates, and depreciating the exchange rate. Advocates of this approach to monetary integration called for institutional arrangements at the domestic and international levels that would centralize authority in a single political body to promote the effective coordination of monetary, exchange rate, and fiscal policies. Monetary integration should be accomplished as quickly as possible in order to capture the joint gains from the international coordination of active economic policies. German governments preferred the technocratic program for monetary integration, which held that government manipulation of the economy does more harm than good. Structural conditions in markets for labor and goods, rather than active fiscal and monetary policies, determine the level of growth and employment. Active economic policies only fuel inflation, because elected governments are unwilling to tighten policy and risk unpopularity. The Germans proposed three solutions for European and domestic economic policy: require that the goal of monetary policy be to keep inflation low, ensure that the monetary authorities do not respond to political pressure by vesting responsibility in an independent central bank, and place constitutional limits on the size of government budget deficits. Integration should occur only after countries have demonstrated their willingness to pursue such stability-oriented policies. These contradictory national preferences remained in place at least until the early 1990s and blocked agreement on creating new European monetary institutions. Agreement on the Maastricht Treaty's plan for monetary union became possible when French and Italian positions shifted toward Germany's technocratic preferences.

Institutional theory's emphasis on the role of information and institutions in fostering cooperation needs to be supplemented with an explanation of national preferences. In the remainder of this section I discuss two specific theories that have been used to explain national preferences regarding European monetary institutions and then describe a research design for evaluating these explanations. Although the discussion focuses on national preferences regarding European monetary institutions, both theories easily can be modified to other empirical contexts involving the creation and alteration of international institutions. They thus have the advantage of being more general than are explanations of European integration that draw attention to the unique structure of the European Union or the "shared commitment in principle to [monetary union] as a central plank in the unification of Europe and to Franco-German reconciliation as its motor" (Dyson, 1999:33).

\section{Constructivism, Idea Diffusion, and Preference Formation}

A central insight of the constructivist approach to the study of international politics is that preferences are plastic in the face of experience, communication, and changing ideas about how the social world operates. Ideas, defined as "beliefs about cause-effect relationships which derive authority from the shared consen- 
sus of recognized elites" (Goldstein and Keohane, 1993:10), define both preferences and the appropriate strategies for achieving these preferences (Wendt, 1994; Finnemore, 1996; Katzenstein, 1996). For example, acceptance of ideas favoring a politicized monetary union prioritizes employment and growth rather than price stability and identifies active fiscal and monetary policies as the best way to achieve these objectives. Constructivists highlight how ideas and thus preferences are shaped by experience and the process of interaction among states. Transnational communication can lead to a process of "idea diffusion" through which decision-makers come to accept a particular idea that interprets the problem that they face and suggests institutional and policy solutions. Idea diffusion facilitates international cooperation and makes bargaining over precise institutional forms more rapid and consensual (Kratochwil and Ruggie, 1986; Haas, 1992; Price, 1998). Ernst Haas, for example, stresses that as decisionmakers "go through the learning process, it is likely that they will arrive at a common understanding [that] ... is likely to trigger a shared understanding of solutions" (Haas, 1990:23-24).

From this perspective, the beliefs and preferences of European governments converged on a technocratic blueprint for monetary integration in three steps (Sandholtz, 1993; Cameron, 1995; Dyson, Featherstone, and Michalopoulos, 1995; McNamara, 1998; Dyson, 1999). First, during the 1970s and early 1980s, decisionmakers in most European countries-but not in Germany-experimented with expansionary fiscal and monetary policies. These policies produced inflation that was much higher than that in Germany but did not have a positive influence on rates of economic growth and employment (see Figure 1). Second, this failure led decision-makers to learn new ideas that changed their preferences about policy goals and the tools used to achieve them. During the 1980s decisionmakers adopted neoliberal ideas that held there is no trade-off between inflation and employment and that rapid increases in the money supply cause inflation. But many specific varieties of neoliberalism existed, including targets for various

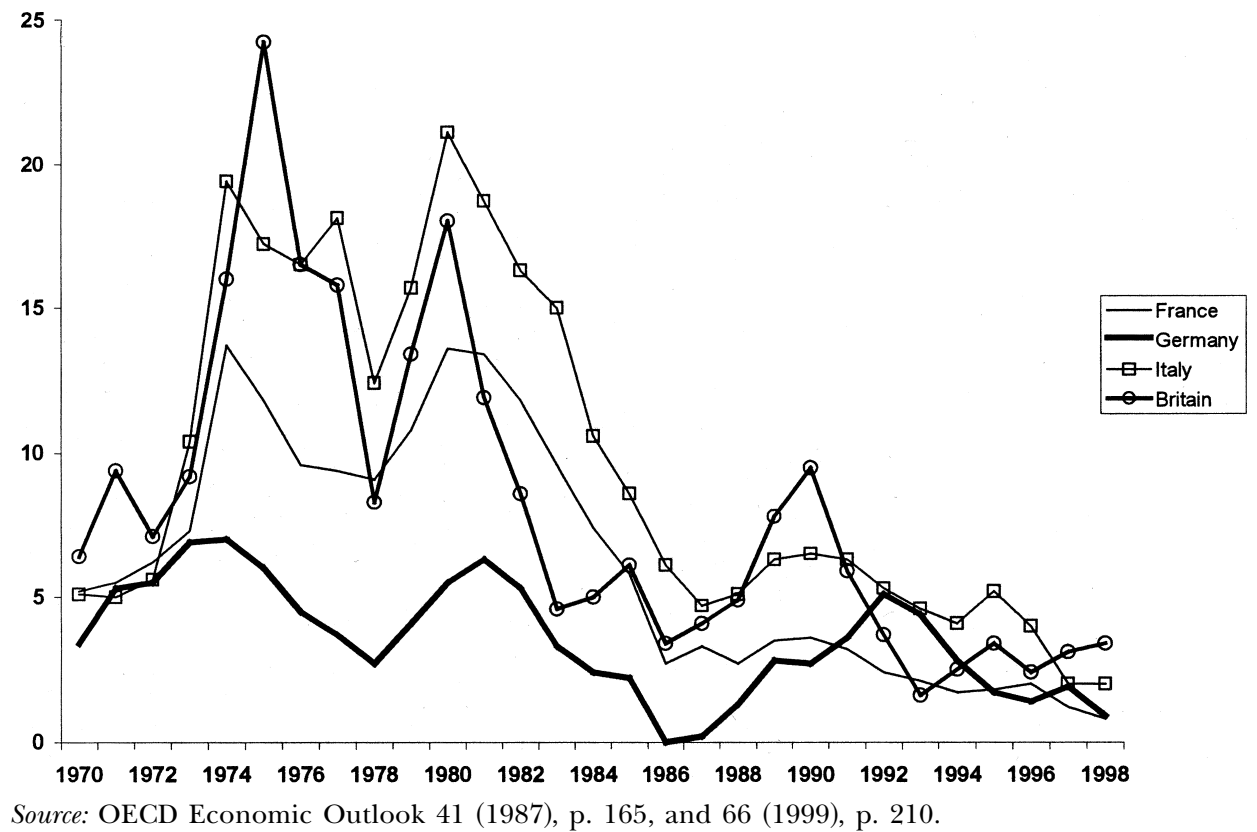

FIG. 1. Annual percentage changes in consumer prices, 1971-88. 
measures of the money supply, the exchange rate, nominal gross domestic product (GDP), and institutional changes such as central bank independence, and it was not clear how to chose among them (Sandholtz, 1993:11-14). German institutions and policies produced better economic outcomes in the turbulent 1970s and 1980s with a technocratic model of neoliberalism that emphasized low inflation, nominal exchange rate stability, and central bank independence. The third step occurred when decision-makers in other states learned about and began to emulate this model, which changed their preferences regarding the rules of European monetary institutions. Whereas during the 1970 s most favored politicized institutions, by the late 1980s they saw the advantages of the technocratic position for achieving low inflation. Sustained interaction in the EMS provided German decision-makers with a forum in which to communicate ideas to European counterparts and to develop shared ideas about appropriate monetary policy goals and instruments (Cameron, 1995; McNamara, 1998:69, 154-156).

\section{Rationalism, Domestic Politics, and Preference Formation}

A rival approach to explaining preference formation draws on the rationalist tradition in the study of international politics. Rationalist theories of national preference formation draw attention to political struggles among utilitymaximizing domestic actors, including politicians, bureaucrats, firms, interest groups, political parties, and labor unions (Putnam, 1988; Evans, Jacobson, and Putnam, 1993; Moravcsik, 1997). Analysts of economic policymaking typically posit that social actors seek to maximize their income and that politicians seek to maximize their political support by implementing policies preferred by some majority of societal actors (Gourevitch, 1986; Rogowski, 1989; Frieden, 1991; Milner, 1997). Institutions structure individuals' preference orderings by privileging certain strategies for utility maximization (Katzenstein, 1978; Zysman, 1983; Hall, 1986; Garrett and Lange, 1995).

Beyond this point work on the rationalist basis of preference formation becomes more complex as individual scholars make subsidiary assumptions and develop specific theories. Two complementary theories exist in the area of preferences regarding international monetary institutions intended to stabilize exchange rates. Both start with the observation that participation in such institutions is costly for national governments, since it requires them to abandon, at least for a time, the ability to pursue a monetary policy that differs from that of other participating states in order to keep their exchange rates stable. The first explanation focuses on the structure of the domestic political economy in order to understand why governments vary in their willingness to sacrifice their monetary policy autonomy. Individuals have different exchange rate policy preferences depending on their degree of integration into the world economy. Those that engage heavily in international trade and investment prefer participation in institutions that will stabilize exchange rates at a competitive level and reduce the riskiness of overseas business, whereas those oriented toward the domestic market will have little interest in such institutions (Frieden, 1991, 1996; Hefeker, 1997). These policy preferences are shaped by the institutions of the domestic financial system. The basic dichotomy here is between countries with credit-based and capital-marketbased financial systems (Zysman, 1983). In countries with credit-based financial systems, such as France, Italy, and Germany, firms raise capital principally through bank loans rather than issues of bonds and equity. The performance of banks is tied closely to that of firms in the real economy. Clients that are not internationally competitive, in part because of unpredictable movements in the exchange rate, find it more difficult to repay borrowed funds. This leads banks to adopt the preferences of their industrial clients for participation in international monetary institutions that will stabilize the exchange rate at a competitive level. A 
small number of banks can aggregate and organize the preferences of many industrial firms and effectively communicate these preferences to decisionmakers. In countries with capital-market-based financial systems, such as Britain, banks do not lend as heavily to industry and are less dependent on industry's performance. Decision-makers thus face fewer pressures to stabilize the exchange rate or to participate in international monetary institutions (Henning, 1994). Based on this, we can expect countries with credit-based financial systems, such as Germany, France, and Italy, to be more willing to sacrifice the power to pursue independent monetary policies in order to participate in international institutions that stabilize exchange rates.

But states preferring stable exchange rates may have different preferences about how to structure an international institution to achieve this goal. The second domestic political explanation looks at how differences in domestic inflation rates influence governments' preferences regarding the rules of international monetary institutions. Sustained differences in inflation rates make it difficult to maintain stable exchange rates because they create strong incentives for investors to shift funds from high-inflation to low-inflation countries. The solution to this problem is for governments to take policy steps that will lead to the convergence of their inflation rates; for example, the central bank of a high-inflation country might raise domestic interest rates to promote price stability, whereas its counterpart in a low-inflation country might relax monetary policy to encourage borrowing and spending that puts upward pressure on prices. Both types of governments find that these steps are politically costly. Tightening monetary policy reduces price increases in a high-inflation country but also cuts into economic growth and employment. A government or central bank in a low-inflation country fears that loosening monetary policy will stimulate domestic demand to unsustainable levels and lead to unwanted increases in prices. Each type of country thus prefers that the other type bear the costs of adjusting economic policy. High-inflation countries prefer international rules that require participating states to pursue potentially inflationary economic policies aimed at promoting economic growth and employment. These steps threaten domestic price stability in low-inflation countries, the governments of which prefer rules that force high-inflation countries to adjust by tightening monetary policy and reducing inflation, even if this threatens to reduce their economic growth rates and to raise unemployment.

In the European context, this conflict between high- and low-inflation countries manifested itself in proposals to alter the rules of the status quo institution, the EMS. States participating in the EMS pledged to keep their exchange rates from fluctuating more than $\pm 2.25 \%$ or $\pm 6 \%$ from central parities by coordinating their monetary policies and by intervening on the foreign exchange market. Central parities could be altered (that is, governments could devalue or revalue their exchange rates) with the agreement of all participants, and the EMS agreement included arrangements for central banks to borrow funds from each other to finance foreign exchange market intervention. Although parts of the EMS agreement implied that all states should adjust their monetary policies and engage in intervention to stabilize parities, in practice the EMS evolved into an asymmetrical arrangement centered on Germany after its creation in 1979. German decision-makers faced fewer pressures to adjust their policies in order to keep exchange rates stable for two reasons. First, strong domestic support for price stability within Germany allowed decision-makers to threaten credibly not to implement policies that would stabilize exchange rates but that might threaten to fuel inflation. Second, Germany's low inflation allowed it to offset market pressures for adjustment in the form of exchange rate changes by purchasing government securities with the currency it issued. Less inflation-averse countries, such as France and Italy until the early 1990s, feared that they would exhaust 
their foreign-currency reserves and be forced to adjust through devaluation, higher interest rates, or real exchange rate appreciation. Unable to agree on a common monetary policy, the participants in the EMS adjusted their parities frequently; between 1979 and 1987, the French franc and Italian lira were devalued four and five times, respectively, and the German mark was revalued seven times (Walsh, 2000:49).

Differences in inflation rates also created different preferences about altering the rules of the EMS. A strong commitment to low inflation and the ability to dominate the existing institution created few incentives for German decisionmakers to agree to changes to the rules of the EMS. They insisted that further monetary integration could occur only after other participating countries reduced their inflation rates to German levels and pledged to create a European institution based on technocratic, anti-inflationary rules: a politically independent European Central Bank to replace the Bundesbank, economic convergence prior to further integration, and strict rules governing national fiscal policies (Henning, 1994; Oatley, 1997; Kaltenthaler, 1998). The other major participants in the EMS, France and Italy, resisted these demands until the early 1990s, since implementing them would have required politically painful tightening of fiscal and monetary policies to reduce inflation. French and Italian decision-makers preferred that the EMS evolve in a more politicized direction that would require participating governments to set common economic policy priorities, which would provide a platform from which the French and Italians could press Germany to relax its monetary policy. These states reached agreement on monetary union in the early 1990s as their inflation rates converged. Greater price stability increased the attractiveness to France and Italy of complying with German preferences regarding the rules of European monetary institutions. They no longer had to pay the political costs of active disinflationary policies and believed that continuing to keep inflation low would be easier than reducing it to German levels. Furthermore, speculative attacks in the foreign-exchange markets against the parities of the franc and lira demonstrated that it would be difficult to maintain stable exchange rates even after inflation rates had converged in the early 1990s (Wyplosz, 1989; De Grauwe, 1993; Grieco, 1995; Moravcsik, 1998).

The domestic-politics explanation of national preferences regarding European monetary institutions yields the following predictions. First, countries with credit-based financial systems-France, Germany, and Italy-should have exhibited greater willingness to stabilize their exchange rates to protect the competitiveness of manufacturing industry and the profitability of the banking sector. This implies that, all other things equal, German, French, and Italian governments preferred to participate in European monetary institutions, whereas British governments showed little interest in such institutions. Second, strong political support for low inflation made German governments unwilling to create institutions that might require them to adjust economic policy. They were willing to enter such institutions only with countries that shared their preference for low inflation and technocratic European monetary institutions designed to limit policy discretion and to produce price stability. High inflation in the 1980s made governments in France and Italy unwilling to enter an institution that would have required them to raise interest rates and to choke off domestic economic growth. They preferred more politicized rules for European monetary institutions that would have allowed them to continue to pursue expansionary economic policies and placed pressure on Germany to do the same in order to achieve exchange rate stability. It was only when their inflation rates fell in the late 1980s that the French and Italians were willing to accommodate German demands for technocratic institutions at the European level. Thus according to this approach British governments showed little interest in European monetary institutions under any circumstances, German governments, under pressure from 
the Bundesbank, were interested in more effective mechanisms for stabilizing exchange rates only on the condition that a new European institution have technocratic rules aimed at keeping inflation low, and French and Italian governments proposed politicized rules for European monetary institutions until their inflation rates fell in the early 1990s, after which they acquiesced to Germany's technocratic preferences.

\section{Hypotheses and Research Design}

The principal goal of this article is to determine the extent to which idea diffusion or domestic politics drove national preferences regarding European monetary institutions in Britain, France, and Italy. Both theories expect that the design of European monetary institutions would reflect German preferences. Evaluating their relative explanatory power thus requires using dependent variables for which each makes different predictions (King, Keohane, and Verba, 1994:224-228). Two such variables are the degree to which governments' institutional preferences converged and the identity of states proposing changes to the status quo.

The idea diffusion explanation holds that preferences regarding the rules of European monetary institutions converged toward Germany's technocratic prescriptions during the 1980s. The failure of economic policy in Britain, France, and Italy to produce growth, employment, and price stability in the 1970 s and 1980 s led politicians to search for alternative policy ideas and to adopt and implement Germany's brand of technocratic economic policies. The preferences that these governments articulate regarding the rules of European monetary institutions therefore should have shifted toward the technocratic position during the 1980s. Decision-makers in all three countries should have adopted some or all of Germany's core institutional preferences for European monetary institutions: a central bank with a commitment to price stability over other goals and independence from the political authorities when implementing monetary and exchange rate policies, and achieving a strong degree of economic convergence among the states before pooling sovereignty over monetary policy. Preference convergence would not have to be complete or cover all economic policy issues for this hypothesis to receive some empirical support.

The domestic-politics explanation holds that national preferences are driven by the structure of the domestic political economy and the inflation rate. From this perspective, British decision-makers should have shown little interest in strengthening European monetary institutions despite a history of policy failure, whereas French, German, and Italian decision-makers should have favored stronger institutions in principle. Differences in inflation rates should have led the latter three states into conflict over the rules governing economic policy. Germany's low inflation gave it the power to resist demands from other countries that it adjust economic policy. France and Italy favored altering the rules of European monetary institutions so that Germany shared the costs of adjusting policies to maintain exchange rate stability. French and Italian bargaining positions therefore should have focused not on adopting the successful German model at the European level but on redesigning European institutions in ways that would give them more voice over German policy. These states should have accepted Germany's technocratic prescriptions only after their inflation rates converged on German levels in the early 1990s. Thus the idea diffusion explanation receives support if proposals for institutional reform gradually converge during the 1980s, whereas the lack of such convergence at least until the 1990s is consistent with the hypothesis derived from the domestic-politics explanation.

These theories also generate different hypotheses about the identity of states proposing changes to European monetary institutions. The domestic-politics expla- 
nation holds that states dissatisfied with the status quo, such as France and Italy, should have proposed reforms but that satisfied states, such as Germany, should not have made such proposals. From the perspective of the idea diffusion explanation, the process of negotiation should have changed over time. After the experience of policy failure in the $1980 \mathrm{~s}$, negotiations should have been best characterized as like-minded individuals in different states reaching quick agreement within a commonly accepted technocratic framework. The state with the record of successful policies, Germany, should have played a leadership role in communicating its successes and proposing appropriate institutional changes (McNamara, 1998:69).

The cases in the following sections comprise all serious proposals by Britain, France, Germany, or Italy to change the rules of the EMS during the 1980s and 1990 s. For each case I trace "the decision process by which various initial conditions are translated into outcomes" (George and McKeown, 1985:35) using the available evidence collected from secondary literature, official statements and documents, journalistic accounts, and confidential interviews with participants. The "initial condition" of interest is the preferences revealed by the initiation of or reaction to proposed rule changes. To measure the extent to which idea diffusion altered preferences, I investigate the motivations for proposing changes that would move the status quo institution in a politicized or technocratic direction and the extent to which a proposal differed from earlier proposals advanced or supported by the same state.

\section{Preference Convergence in the European Monetary System}

This section assesses the extent to which institutional preferences and bargaining strategies converged during the 1980s. Idea diffusion theory expects states experiencing policy failure-Britain, France, and Italy-to learn about and begin to adopt preferences consistent with technocratic ideas for monetary integration. There is little evidence that this occurred; instead, states maintained their preferences for politicized institutions (France, Italy) or for no monetary integration at all (Britain).

\section{European Monetary System Reform, 1982-84}

In March 1982 the European Commission proposed reforms to the design of the EMS that included multilateral surveillance of economic policies and more required central bank intervention to stabilize exchange rates. Both steps would pressure the German central bank, the Bundesbank, to emulate the policies of less inflationaverse participants in the EMS. Surveillance would give these states a forum in which to formally pass judgment on German economic policy; greater intervention obligations might force the Bundesbank to increase the German money supply by purchasing depreciating EMS currencies. The French, Italian, and Belgian governments all backed the commission's proposals and also advocated creating the European Monetary Fund envisioned in the original EMS agreement in order to institutionalize the new foreign-exchange market intervention requirements. The Bundesbank and the German government rejected these proposals and called on other states to reduce their inflation rates before altering the design of the EMS (Stephens, 1982; Wyles, 1982). Germany blocked a similar commission proposal in early 1984 that Italy and Belgium supported (Fabra, 1984; Financial Times, 1984a, 1984b).

\section{Single European Act}

European Commission President Jacques Delors proposed incorporating the EMS into the Treaty of Rome and creating the European Monetary Fund when states 
negotiated treaty changes that would create a single European market. If successful, Delors' proposals would have given the commission formal power to propose institutional and policy changes. The commission's traditional monetary allies, France, Italy, and Belgium, supported these proposals; the British and Germans opposed them. The British, whose currency did not participate in the system's exchange rate mechanism (ERM), which established central parities, objected to any changes that would further separate them from the other states. Germany opposed changes until there was greater convergence toward economic stability (Peel, 1985; Dyson, 1994:117-118). In December 1985 states agreed to incorporate the EMS into the Single European Act, but the Germans and British succeeded in limiting all references to the system's current operating mechanisms and required that further development toward monetary union could occur only through treaty changes, including the successful conclusion of an intergovernmental conference and ratification by all members of the European Community.

\section{Franco-German Economic Council}

In late 1987 the French and German governments began negotiations over a bilateral economic council composed of finance and economics ministers and central bank governors that would meet quarterly to coordinate economic policy. The French hoped the council would give them the institutional leverage to undercut the Bundesbank's focus on low inflation when this conflicted with exchange rate stability. Bundesbank opposition led German Chancellor Helmut Kohl to declare before the Bundestag that the treaty would not weaken the central bank's independence (Dyson, 1994:123-125).

\section{Basle-Nyborg Accords}

The French continued to complain about the Bundesbank's priority of keeping inflation low, and in 1987 French Finance Minister Edouard Balladur pressed for further institutional changes that resulted in the nonbinding Basel-Nyborg accords. As in earlier negotiations, the French, Belgians, and Italians wanted reforms that would distribute the burdens of policy adjustment more symmetrically among countries with appreciating and depreciating currencies. They called for a multilateral obligation to engage in foreign-exchange market intervention before currencies reached their fluctuation margins (so-called intramarginal intervention), greater reliance on the EMS "divergence indicator," which would identify the source of exchange rate tension as the country whose exchange rate was diverging most markedly from the EMS average, and more surveillance of national economic policies. These changes would have required the German and Dutch central banks to engage in potentially inflationary foreign exchange intervention to maintain the system's stability (Peel, 1987; Renard, 1987).

The Basle-Nyborg agreement of September 1987 modestly reduced the asymmetry of EMS intervention rules but did not include provisions for more required intervention, greater surveillance, or use of the divergence indicator. Specific measures of the Basel-Nyborg accords included increased short-term credits among central banks for financing intervention and the extension of the initial credit repayment period to three-and-one-half months. But Germany insisted that other governments promise to stop using capital controls and instead raise interest rates to defend their exchange rates. This made it less likely that central banks would draw on the new financing mechanisms that Germany disliked (Peel and Stephens, 1987; Gros and Thygesen, 1992:94-99; Dyson, 1994: 121-123). 


\section{Monetary Union}

Balladur recognized that after the removal of capital controls a restrictive German monetary policy would be transmitted to the rest of Europe and restrain growth and investment. In early 1988 he circulated a memorandum to fellow finance and economics ministers again criticizing the rules of the EMS and arguing that "the rapid pursuit of the monetary construction of Europe is the only possible solution" (quoted in Gros and Thygesen, 1992:312; see also Balladur, 1988). French Prime Minister Jacques Chirac also supported reforming the EMS and criticized the Bundesbank's intervention policies, stating that "it is not right that the Bundesbank only intervenes against one currency [the dollar] and refuses to do so against any other currency" and describing the EMS as a "mark zone" (Le Monde, 1988). In late January Balladur proposed bringing all European Community currencies into the narrow band of the ERM, binding guidelines for economic policies, and creating a European Central Bank and common currency. No mention was made of central bank independence or the importance of economic convergence (Balleix, 1994). Balladur's motivation was quite explicit: "Over a number of years Germany has been able to accumulate external trade surpluses because of insufficient internal growth without any mechanism being in place which would prompt it to accelerate the pace of its economy" (quoted in MacDonald, 1988). Shortly thereafter German Foreign Minister Hans-Deitrich Genscher also advocated further monetary integration, although his proposal was more consistent with technocratic ideas. Together these calls led the Hanover European Council of heads of state and government to appoint a committee chaired by Delors and composed of national central bankers and independent experts to propose a plan for moving to full monetary union.

French officials originally envisioned that the Delors Committee's report would include immediate reforms to the EMS and expressed little initial interest in Germany's more technocratic ideas. For example, during the committee's deliberations, Jacques de Larosière of the Banque de France, supported by Delors, the Italians, and the Spanish, proposed pooling reserves for foreign-exchange market intervention and explicit deadlines for creating stronger European monetary institutions (confidential interview with former Banque de France official, Paris, 1995). This conflicted with the Bundesbank's insistence that monetary policy coordination should be the product of long-term economic convergence (Pöhl, 1988). French officials later complained that the committee did not incorporate their proposal or in general suggest sufficiently rapid moves toward greater policy coordination. But they quickly recognized that the Bundesbank would require long-term convergence of economic policies prior to implementing substantial reforms, and they supported the Delors Committee's relatively elaborate plan for monetary union (Whelan, 1989; confidential interview with former Banque de France official, Paris, 1995). Italian decision-makers also were interested in greater monetary cooperation. In a memorandum to the Council of Economics and Finance Ministers (Ecofin), Italian Treasury Minister Guiliano Amato called for reforms to the EMS to give it more symmetry and stated that full liberalization of capital movements in the European Community would require some mechanism to recycle payments surpluses from strong to weak currency countries (Amato, 1988). Neither de Larosière's proposal nor Amato's memorandum discussed Germany's key technocratic demands for an independent central bank or the role of economic convergence prior to further monetary integration.

Britain was the only country to reject out of hand the idea of monetary union on any terms. British Prime Minister Margaret Thatcher and Chancellor Nigel Lawson described monetary union as "an unacceptable 'surrender' of national sovereignty” (Howe, 1994:533-534; see also Dyson, 1994:134). After discussing a draft of the Delors Committee's report in February 1989, Thatcher and Lawson 
pressed the British representative, Robin Leigh-Pemberton of the Bank of England, to attach an independent statement opposing its conclusions. Leigh-Pemberton refused, preferring to work inside the committee to change some of the wording of its report (Lawson, 1993:907-909; Thatcher, 1993:708; Howe, 1994:576-577).

In April 1989 the committee proposed a gradual three-stage transition to full monetary union. It suggested the creation of a European system of central banks with a European Central Bank independent of political control and "committed to the objective of price stability" as the key decision-making body. It advocated "binding rules" covering national fiscal policies to prevent "uncoordinated and divergent national budgetary policies [that] would undermine monetary stability" (Committee for the Study of Economic and Monetary Union, 1989, paragraph 23). The details of the Delors Committee's report reflected the influence and concerns of the president of the Bundesbank, Karl-Otto Pöhl. The Bundesbank's preferences are evident in the provisions for an independent central bank with the goal of price stability and fiscal convergence prior to monetary integration, none of which the British, French, or Italians initially supported.

\section{Analysis}

There is little evidence of a convergence toward Germany's preferences for technocratic institutions from 1980 to 1987. On six occasions the European Commission and states other than Germany proposed changes to European monetary institutions. Although the substantive proposals differed, they all had the goal of creating more politicized rules that would reduce German influence over the monetary and exchange rate policies of other states. Concerns about the domestic political costs of the status quo institution, the EMS, motivated the initiation and content of proposals for institutional change. Consider French reform proposals (all of which Italy supported). In 1982, the government favored changing the rules of the EMS to require that countries with appreciating currencies-notably Germany-relax monetary policy by intervening on the foreignexchange markets to support depreciating ERM currencies such as the franc. They also called for surveillance of national economic policies and greater reliance on the ERM's divergence indicator, both of which would have identified German economic policy as diverging from the European average. The French made remarkably similar proposals at the end of the decade. Balladur's initial proposals in 1987, which resulted in the Basle-Nyborg accords, called for stronger surveillance, reviving the divergence indicator, and increased central bank swaps to finance required intervention. The consistency of French reform proposals is striking because the Mitterrand government's experiment with expansionary monetary and fiscal policies during the world recession of the early $1980 \mathrm{~s}$ is viewed by many as an episode of unmitigated policy failure (for example, see Sachs and Wyplosz, 1986; Risse, Engelmann-Martin, Knopf, and Roscher, 1999). This failure did lead the government to place more importance on reducing inflation. But it did not lead to a significant change in the government's positions regarding the design of European monetary institutions. A similar consistency marked the British position. British governments kept the pound outside of the ERM until 1990, remained aloof during negotiations to change more technical elements of the EMS, and opposed treaty changes that would strengthen the system.

German behavior also corresponds with the expectations of the domesticpolitics explanation. Germany did not propose changes to European monetary institutions. German negotiators vetoed every proposal but one and did not put forward any ideas about reforming the EMS other than to call on states to reduce inflation and budget deficits. And in the one case where it agreed to institutional changes, the Basel-Nyborg reforms, Germany extracted as side payments the 
elimination of capital controls and promises to rely on interest rate changes rather than foreign-exchange market intervention to stabilize exchange rates.

\section{Bargaining over Monetary Union}

The Delors Committee left important questions about monetary union unanswered. Subsequent intergovernmental negotiations took up these questions and culminated in the Treaty on European Union finalized in Maastricht in late 1991. The domestic-politics and idea diffusion explanations have different expectations about preferences regarding the terms of monetary union. Ideational analysis predicts at least some preference convergence regarding the core technocratic ideas for integration-central bank independence and convergence toward monetary and fiscal stability before integration-because decision-makers had learned that this would result in superior economic performance. The domestic-politics approach expects substantial differences in preferences, since France and Italy favored monetary union as a way to reduce German influence on their monetary policies and Britain remained outside of the EMS and was not interested in further institutional developments.

\section{Central Bank Independence}

German negotiators insisted before the convening of the Delors Committee that there would be no monetary union without central bank independence. Foreign Minister Genscher's proposals of early 1988 included an independent European Central Bank. Chancellor Kohl supported this position in January and Finance Minister Gerhard Stoltenberg did so in March (Reuters, 1988). The French had misgivings about central bank independence. The finance ministry opposed abandoning control over the Banque de France, but Mitterrand and Foreign Minister Roland Dumas moderated this position to make monetary union acceptable to Germany. This was a secondary issue for the British, given their opposition to participating in a single currency, and their involvement ended when the government secured a clause in the Maastricht Treaty allowing it to stay out of monetary union and to retain control over the Bank of England (Bini-Smaghi, Padoa-Schioppa, and Papadia, 1994:23; Dyson et al., 1995:469; confidential interview with Banque de France official, Paris, 1995).

German pressure led the French to agree shortly before the Rome European Council of October 1990 that the European Central Bank and national central banks would be politically independent and should have price stability as their mandate. By late November the Committee of Central Bank Governors produced a central bank statute that resembled the federal structure of the Bundesbank and gave the European Central Bank control over external exchange rate policy. But two months later French Finance Minister Bérégovoy backed away from the earlier commitment to central bank independence and announced that the French cabinet preferred a "fully democratic economic government" in the form of a strengthened Ecofin that would serve as a political counterweight to a European Central Bank. The French suggested that control over exchange rate policy rest with Ecofin acting by qualified majority. The Bundesbank and German government continued to insist on full independence for the European Central Bank, although they did agree to modest concessions in the area of exchange rate policy (Graham, 1990; Italianer, 1993:65; Balleix, 1994).

The Maastricht Treaty created an independent European Central Bank and national central banks with explicit mandates for price stability and divided responsibility over external monetary policy between the European Central Bank and Ecofin. Acting by a unanimous vote after consulting with the European Central Bank, Ecofin may peg the single currency to foreign currencies in the 
context of an undefined "exchange rate system." However, in the absence of such a system, Ecofin was limited to deciding on "general orientations" for exchange rate policy by a qualified majority, and these must be "without prejudice to the primary objective" of the European Central Bank to maintain price stability. Most conclude that this arrangement will make it difficult for governments to agree on an external monetary policy over the opposition of the European Central Bank (Henning, 1997).

\section{Economic Convergence}

Two issues dominated the negotiations over the extent to which economic convergence should precede monetary union: the definition of criteria states would have to meet and the desirability of preestablished deadlines for moving between the stages of monetary union laid out in the Delors Committee's report.

At the urging of the Bundesbank and other central banks, the Delors Committee emphasized the importance of economic convergence for a stable single currency (Marsh, 1988). The crucial conflict in the intergovernmental negotiations was over which convergence criteria to choose and how to define them. The negotiators had particular difficulty agreeing on the degree of fiscal policy convergence necessary for participation in full monetary union. Italian budget deficits averaged over 10\% of GDP in the 1980s, leading the Italian negotiators to favor "binding procedures rather than binding rules for budget deficits" and the use of "objective criteria only as a yardstick" (Bini-Smaghi et al., 1994:13-15; see also Carli, 1993:406-412; Italianer, 1993:63, 69-70). The German government and Bundesbank stressed the importance of multilateral control over national fiscal policies to ensure that participants' budgetary positions would not undermine monetary stability (Deutsche Bundesbank, 1990; Marsh, 1992:211-213; Jochimsen, 1993; Nölling, 1993:126, 161, 182; Dyson, 1994:138-141; Kaltenthaler, 1998:81). The German draft treaty of 1991 advocated binding, objective, and quantitative criteria, especially for budget deficits and the stock of government debt. The French were willing to accept the German position on this issue because of their strong fiscal position, and the French draft treaty advocated sanctions against states whose deficits exceeded a still undefined criterion (Italianer, 1993:63, 69-70; confidential interviews with a French representative to the intergovernmental conference on monetary union, Paris, 1995, and with European Commission official, Brussels, 1995).

The treaty corresponded closely to German preferences. It stated that, for the calendar year before the European Council decided to move to full monetary union, a member state's budget deficit must be below $3 \%$ of GDP unless it "has declined substantially and continuously and reached a level that comes close to [this] reference value ... or the excess is only exceptional and temporary," and a member state's debt-to-GDP ratio had to be below $60 \%$ "unless the ratio is sufficiently diminishing and approaching the reference value." The other criteria for participation were that a state had not devalued on its "own initiative" for two years, and in the previous year had had an inflation rate within $1.5 \%$, and long-term interest rates within $2 \%$, of the average rates of the three member states with the lowest rates.

The second element concerning economic convergence was the timing of the transitions between the three stages. The French and Italians advocated setting deadlines in advance for all three stages to provide the political impetus necessary for the creation of full monetary union. The German government and Bundesbank opposed political deadlines on the grounds that they contradicted the principle that economic performance converge before proceeding with integration. The British opposed all attempts to set deadlines except for the start of the first stage. German negotiators agreed to set deadlines for the first and 
second stages but resisted a deadline for the crucial third stage, which would introduce the single currency.

The German draft treaty of early 1991 called for the European Council to make the decision to move to the third stage by unanimity only when a majority of member states met the convergence criteria. French negotiators opposed this formulation because it did not guarantee that the third stage would ever begin. At the very end of the intergovernmental conference the French proposed, with Italian support, that if the European Council could not agree to move to the third stage by a qualified majority of member states meeting the convergence criteria in 1996, it would begin automatically in January 1999 and include all states meeting the convergence criteria (except for Britain and Denmark, who successfully demanded "opt-out" clauses that would allow them not to participate). This was intended to provide "an unambiguous signal in favor of EMU [economic and monetary union]," while the application of the convergence criteria appeased the German desire for monetary union only with low-inflation countries (Marsh, 1992:206-209; Jochimsen, 1993:196; Italianer, 1993:70).

\section{Analysis}

The evidence from the monetary union negotiations provides some support for the idea diffusion explanation's hypothesis of preference convergence. In the end the French and Italians did accept Germany's technocratic demands regarding central bank independence and economic convergence. The similarities between the European Central Bank and the Bundesbank indicate that Germany's domestic institutions served as a model for the negotiators. Yet there is more evidence that preferences continued to diverge in the manner expected by the domestic-politics explanation. The French and Italians initially opposed making central bank independence or the convergence criteria part of the treaty. Rather than sincerely attempting to copy German institutions, the French and Italians probably believed that German negotiators would insist on those points. The French and Italians also pressed hard for setting deadlines, a position inconsistent with Germany's well-known technocratic preferences. The concessions of the French and Italians are consistent with the expectation of the domestic-politics explanation that lower inflation in the early 1990s reduced the costs of adhering to technocratic rules for economic policy. For example, the improvement in the French fiscal position during the 1980s made the government rather indifferent to Germany's demands for convergence criteria, since it (wrongly) expected to meet these criteria easily. Italian governments, in contrast, continued to oppose the fiscal-policy convergence criteria in the knowledge that they might prevent Italy from participating in monetary union. And the British continued to show no interest in participating in monetary union, despite the fact that the government experienced further policy failure in the form of high inflation and a deep recession during the negotiations that preceded the signing of the Maastricht Treaty.

\section{The Transition to Monetary Union}

\section{The Stability Pact}

During the 1990s both the French and German governments pushed for changes to the institutions established in the Maastricht Treaty. Consistent with their long-held technocratic preferences, the German government and Bundesbank proposed adding a Stability Pact to the treaty that would punish states pursuing expansionary fiscal policies. The Germans suspected that some countries, such as Italy and Spain, might make short-term sacrifices to meet the fiscal-convergence 
criteria for participation in the single currency without changing the underlying political forces that produced large deficits. German negotiators preferred that the pact enumerate quantitative criteria that states would have to meet to avoid automatic penalties and wanted Ecofin to have the ability to impose sanctions as soon as it detected a large deficit (Ungerer, 1997:279).

Other states agreed that some mechanism for coordinating fiscal policy would be useful but, with the exception of the Netherlands, forcefully criticized the content of the proposed Stability Pact. They favored a more flexible and politicized approach whereby Ecofin would exercise its judgment rather than follow quantitative criteria when evaluating fiscal-policy sustainability and would take action only when an excessive deficit proved to be more than transitory. The Juppé government in France led this counterattack on the German provisions for the Stability Pact with the strong backing of governments in Italy, Spain, and most other member states. These governments feared that the proposed pact's quantitative and automatic provisions would make it difficult to use fiscal policy to promote economic growth and to reduce unemployment. This issue became pressing in the mid-1990s as a deep recession led budget deficits to increase to well above 3\% of GDP in most European countries, including France and Germany. These deficits led the French to weaken their earlier commitment in the Maastricht Treaty negotiations to adhere to Germany's strict fiscal-policy preferences. These differences were resolved in Germany's favor at the European Council summit meeting in Dublin in December 1996. The Dublin agreement required member states to keep their budgets near balance over the medium term and to submit annual "stability programs" outlining future fiscal policy to Ecofin. The pact defined a deficit larger than 3\% of GDP as excessive and subject to sanctions unless the member state's rate of economic growth declined by more than $2 \%$. In cases where the decline in economic growth was between 0.75 and $2 \%$, Ecofin would decide by qualified majority vote if an excessive deficit existed. Under no circumstances could output declines of less than $.75 \%$ justify an excessive deficit. Germany did make two minor concessions to other member states' demands, agreeing to give governments one year to correct an excessive deficit and to give the agreement the more positive-sounding name of the Stability and Growth Pact.

The Jospin government, elected shortly before the May 1997 European Council summit in Amsterdam that would give formal approval to the pact, objected to the Dublin agreement's limitations of fiscal policy and insisted on renegotiating it. The Italian government initially backed French demands for greater emphasis on promoting employment and growth and centralizing economic policy authority to create a political counterpart to the European Central Bank (Owen, 1997; La Repubblica, 1997). The Germans refused to consider substantially altering the Stability Pact but did agree to minor changes in order to prevent French opposition from threatening the successful conclusion of the amendments to the Treaty of Rome finalized in Amsterdam. The revised pact created an Employment Committee that would monitor labor market policies and have the power to recommend (but not require) policy changes that might reduce unemployment. It also requested that the European Investment Bank increase its lending to small and medium-sized firms and to Europe-wide infrastructure projects. German negotiators successfully insisted that these measures require little new spending and that the remaining elements of the pact remain unchanged (Norman, 1997; Financial Times, 1997; Papitto, 1997).

\section{The Euro Council}

The French priority remained the creation of a political body that would equal the European Central Bank. They responded to the Stability Pact by proposing 
the creation of a Euro Council, composed of finance ministers only from member states adopting the single currency, that would coordinate national fiscal policies, supervise the Stability Pact, take responsibility for external exchange rate policy, and advise the European Central Bank on monetary policy. To the Germans this looked like a revival of French demands during the negotiation of the Maastricht Treaty for an "economic government" that might influence monetary policy. Bundesbank and German government officials opposed the French proposal until winning key concessions in March 1997. These included French agreement that the Euro Council would not issue advice on monetary policy or otherwise undermine the independence of the European Central Bank, that the full Ecofin Council would retain responsibility for exchange rate policy laid out in the Maastricht Treaty, and that the Euro Council would be an informal and consultative institution not subject to the European Union's regular decisionmaking procedures (Les Echos, 1997; La Tribune, 1997).

\section{Analysis}

Preferences regarding European monetary institutions did not converge during the 1990s. The French and Italians continued to propose the centralization of economic policy authority in political bodies and giving greater attention to employment and the coordination of countercyclical fiscal policies, whereas German preferences leaned in the opposite direction, toward buttressing the independence of the European Central Bank and limiting fiscal policy flexibility. German negotiators succeeded in pushing through the Stability Pact's requirements for the management of the single currency over the opposition of most other states, although they did concede that states could temporarily run excessive deficits under restricted circumstances and that the Ecofin Council would have a modest degree of political leeway in interpreting national fiscal policies. The German government also succeeded in curtailing the long-standing French desire for a political counterweight to the European Central Bank by insisting that the Euro Council remain an informal consultative body that would not question the central bank's power to make decisions regarding monetary policy.

\section{Conclusions}

Table 1 summarizes the evidence presented in the preceding three sections. Recall that the idea diffusion and domestic-politics explanations generated different expectations about changes in preferences over time and the identity of states proposing changes to the status quo. On both counts most of the evidence supports the domestic-politics explanation. Britain expressed little interest in monetary integration, and the French and Italian governments consistently advocated politicized rules from 1982 to 1997. This provides little support for idea diffusion theory, which expects that preferences in these countries would have converged on technocratic ideas. Also consistent with the expectations of the domestic-politics explanation is the fact that all but two of the ten proposals for changing the status quo institution originated from France and Italy, the two states that participated in the German-dominated EMS. Only in the cases of the intergovernmental conference on monetary union and the Stability Pact did Germany play a leading role in proposing institutional change. Yet these cases arguably are consistent with a focus on the domestic political determinants of national preferences. Germany's proposals during the intergovernmental conference were a reaction to French calls for a single currency backed up by politicized institutions, and the German government's leadership role in the negotiation of the Stability Pact was motivated by its concern that implementation of the Maastricht Treaty might not provide sufficient restraint of national fiscal policies. 
TABle 1. Proposals to Change Rules of European Monetary Institutions

\begin{tabular}{|c|c|c|}
\hline Cases & $\begin{array}{l}\text { States Proposing } \\
\text { Changes }\end{array}$ & Proposed Change from Status Quo \\
\hline $\begin{array}{l}\text { Reforms to EMS } \\
\quad(1982-84)\end{array}$ & France, Italy & $\begin{array}{l}\text { Politicized: multilateral surveillance, creation of } \\
\text { European Monetary Fund, greater intervention } \\
\text { obligations }\end{array}$ \\
\hline $\begin{array}{l}\text { Single European Act } \\
\text { (1985) }\end{array}$ & $\begin{array}{l}\text { France, Italy } \\
\text { (supporting } \\
\text { European } \\
\text { Commission) }\end{array}$ & $\begin{array}{l}\text { Politicized: creation of European Monetary Fund, } \\
\text { incorporation of EMS into Treaty of Rome to give } \\
\text { commission power to propose policy and } \\
\text { institutional changes }\end{array}$ \\
\hline $\begin{array}{l}\text { Franco-German } \\
\text { Economic Council } \\
(1987-88)\end{array}$ & France & $\begin{array}{l}\text { Politicized: bilateral treaty coordinating economic } \\
\text { and monetary policies }\end{array}$ \\
\hline $\begin{array}{l}\text { Basle-Nyborg Accords } \\
\quad(1987)\end{array}$ & France & $\begin{array}{l}\text { Politicized: multilateral surveillance, greater } \\
\text { intervention obligations }\end{array}$ \\
\hline $\begin{array}{l}\text { Monetary Union } \\
\quad(1987-88)\end{array}$ & France, Italy & $\begin{array}{l}\text { Politicized: single currency, European Central Bank, } \\
\text { binding economic policy guidelines }\end{array}$ \\
\hline \multirow{3}{*}{$\begin{array}{l}\text { Intergovernmental } \\
\text { Conference on } \\
\text { Monetary Union } \\
(1990-91)\end{array}$} & Germany & $\begin{array}{l}\text { Technocratic: central bank independence, fiscal } \\
\text { policy convergence, weak coordination during } \\
\text { transition }\end{array}$ \\
\hline & France & $\begin{array}{l}\text { Politicized: weakening of central bank independence, } \\
\text { deadlines for stages of monetary union }\end{array}$ \\
\hline & Italy & $\begin{array}{l}\text { Politicized: dilution of convergence criteria, deadlines } \\
\text { for stages of monetary union }\end{array}$ \\
\hline $\begin{array}{l}\text { Stability Pact } \\
\quad(1994-97)\end{array}$ & Germany & $\begin{array}{l}\text { Technocratic: quantitative limits on fiscal policy with } \\
\text { fines for violations }\end{array}$ \\
\hline $\begin{array}{l}\text { Euro Council } \\
\quad(1996-97)\end{array}$ & France & $\begin{array}{l}\text { Politicized: active fiscal policy coordination, } \\
\text { exchange rate policy, advise central bank on } \\
\text { monetary policy }\end{array}$ \\
\hline
\end{tabular}

These findings have implications for both institutional theory and constructivism. They lend support to the contention that scholars need to devote as much attention to distributional issues as they have to explaining how international institutions promote efficiency and cooperation (Krasner, 1991; Knight, 1992; Fearon, 1998). Both politicized and technocratic blueprints for monetary union would have promoted cooperation in an efficient manner but in doing so would have required that states adjust their policies and priorities in undesired directions. No state viewed European monetary institutions solely or even principally in terms of efficiency; instead, states saw them as ways to achieve ends that were important for domestic political reasons, and their specific proposals reflected these political considerations. States dissatisfied with the status quo pressed for institutional changes, whereas those content with the status quo resisted such proposals.

The findings also are an important challenge to work in the constructivist tradition that treats preferences as endogenous to processes of policy failure, international interaction, and idea diffusion. The findings lead to the conclusion that domestic political arrangements are more durable in the face of policy failure than much of the constructivist literature assumes. Future research in this tradition needs to pay more attention to how ideas resonate with domestic political coalitions, ideologies, and institutions in order to understand the conditions under which idea diffusion will and will not occur. 
A useful starting point would be to draw inspiration from the literature on internationalization and domestic politics, where a significant amount of work has explored how domestic politics shapes the influence of external developments (Keohane and Milner, 1996). This literature suggests two areas of investigation. First, scholars interested in idea diffusion could systematically investigate how domestic groups favoring or opposing a new idea use political resources to achieve their ends. This would require carefully specifying the relevant groups inside and outside of the state, their preference orderings, and their access to relevant political resources, steps that few scholars in the constructivist tradition have taken (but see Checkel, 1999; Dyson, 1999). Second, the literature on internationalization and domestic politics also highlights the importance of domestic institutions in refracting pressures from abroad and has produced a number of specific hypotheses that could be applied to the area of idea diffusion (Garrett and Lange, 1995; Rogowski, 1999). Moving in these directions would be one way that constructivists could develop more sophisticated models of idea diffusion.

\section{References}

Амато, G. (1988) Un Motore per lo SME [A Motor for the EMS]. Il Sole 24 Ore, 25 February, 1.

Andrews, D. (1993) "The Global Origins of the Maastricht Treaty on EMU: Closing the Window of Opportunity." In The State of the European Community, vol. 2: The Maastricht Debates and Beyond, edited by A. W. Cafruny and G. G. Rosenthal, pp. 107-123. Boulder, CO: Lynne Rienner.

Axelrod, R. (1984) The Evolution of Cooperation. New York: Basic Books.

Balladur, E. (1988) Memorandum sur la Construction Monétaire Européenne [Memorandum on European Monetary Integration]. ECU Newsletter, March.

Balleix, C. (1994) La banque centrale européenne dans le discours politique français [The European Central Bank and French Political Discourse]. La Revue Politique et Parlementaire (NovemberDecember):38-45.

Bini-Smaghi, L., T. Padoa-Schioppa, And F. Papadia (1994) The Transition to EMU in the Maastricht Treaty. Essays in International Finance No. 194. Princeton: Department of Economics, Princeton University.

Cameron, D. R. (1995) "Transnational Relations and the Development of European Economic and Monetary Union.” In Bringing Transnational Relations Back In, edited by T. Risse-Kappen, pp. 3778. New York: Cambridge University Press.

Carli, G. (1993) Cinquant'anni di Vita Italiana [Fifty Years of Italian Life]. Bari, Italy: Laterza.

Checkel, J. (1999) Norms, Institutions, and National Identity in Contemporary Europe. International Studies Quarterly 43:83-114.

Commission of the European Communities (1990) One Market, One Money: An Evaluation of the Potential Benefits and Costs of Forming an Economic and Monetary Union/Commission of the European Communities. Luxembourg: Office for Official Publications of the European Communities.

Committee for the Study of Economic and Monetary Union (1989) "Report on Economic and Monetary Union in the European Community." Committee for the Study of Economic and Monetary Union, Brussels, Belgium, April 12.

De Grauwe, P. (1993) The Political Economy of Monetary Union in Europe. European Economy 16:653-661.

Deutsche Bundesbank (1990) Establishment of an Economic and Monetary Union in Europe. Deutsche Bundesbank, Frankfurt, Germany, September 19.

Dyson, K. (1994) Elusive Union: The Process of Economic and Monetary Union in Europe. London: Longman.

Dyson, K. (1999) The Franco-German Relationship and Economic and Monetary Union: Using Europe to "Bind Leviathan." West European Politics 22:25-44.

Dyson, K., K. Featherstone, and G. Michalopoulos (1995) Strapped to the Mast: EC Central Bankers between Global Financial Markets and Regional Integration. Journal of European Public Policy 2:465-487.

Evans, P., H. Jacobson, And R. Putnam, eds. (1993) Double-Edged Diplomacy. Berkeley and Los Angeles: University of California Press.

Fabra, P. (1984) L'ECU est-il une monnaie [Is the ECU a Currency]? Le Monde, March 20, 21.

Fearon, J. D. (1998) Bargaining, Enforcement, and International Cooperation. International Organization 52:269-305. 
Financial Times (1984a) Ortoli Calls on Member States to Boost EMS. Jan. 25, 2.

Financial Times (1984b) EMS Wins Plaudits but No Promises for Growth. March 13, 1.

Financial Times (1997) Santer Looks to Secure EU Deal on Jobs. June 12.

Finnemore, M. (1996) National Interests in International Society. Ithaca: Cornell University Press.

Frieden, J. A. (1996) The Impact of Goods and Capital Market Integration on European Monetary Politics. Comparative Political Studies 29:193-222.

Frieden, J. A. (1991) Debt, Development, and Democracy: Modern Political Economy and Latin America, 1965-1985. Princeton: Princeton University Press.

Garrett, G. (1993) The Politics of Maastricht. Economics and Politics 5:105-123.

Garrett, G., AND P. LANGe (1995) Internationalization, Institutions, and Political Change. International Organization 49:627-655.

George, A., And T. McKeown (1985) Case Studies and Theories of Organizational Decision Making. Advances in Information Processing in Organizations 2:21-58.

Goldstein, J., And R. O. Keohane (1993) "Ideas and Foreign Policy: An Analytical Framework." In Ideas and Foreign Policy, edited by J. Goldstein and R. Keohane, pp. 3-30. Ithaca: Cornell University Press.

Gourevitch, P. (1986) Politics in Hard Times. Ithaca: Cornell University Press.

Graham, G. (1990) French Back Democratic Control of Eurofed. Financial Times, Dec. 6, 2.

Grieco, J. M. (1995) The Maastricht Treaty, Economic and Monetary Union, and the Neo-Realist Research Programme. Review of International Studies 21:21-40.

Gros, D., AND N. Thygesen (1992) European Monetary Integration. London: Longman.

HaAs, E. (1990) When Knowledge Is Power. Berkeley and Los Angeles: University of California Press.

HaAs, P. M. (1992) Introduction: Epistemic Communities and International Policy Coordination. International Organization 46:1-35.

Hall, P. (1986) Governing the Economy. New York: Oxford University Press.

Hefeker, C. (1997) Interest Groups and Monetary Integration. Boulder, CO: Westview.

Henning, C. R. (1994) Currencies and Politics in the United States, Germany, and Japan. Washington, DC: Institute for International Economics.

Henning, C. R. (1997) Cooperating with Europe's Monetary Union. Washington, DC: Institute for International Economics.

Howe, G. (1994) Conflict of Loyalty. London: Macmillan.

Ikenberry, G. J., And C. A. Kupchan (1990) Socialization and Hegemonic Power. International Organization 44:283-315.

Italianer, A. (1993) Mastering Maastricht. In Economic and Monetary Union: Implications for National Decision-Makers, edited by K. Gretschmann, pp. 51-113. Dordrecht, the Netherlands: Martinus Nyjoff.

Jochimsen, R. (1993) "Economic and Monetary Union: A German Central Banker's Perspective." In Economic and Monetary Union: Implications for National Policy-Makers, edited by K. Gretschmann, pp. 195-213. Dordrecht, the Netherlands: Martinus Nyjoff.

Kaltenthaler, K. (1998) Germany and the Politics of Europe's Money. Durham: Duke University Press.

Katzenstein, P. J. (1978) Between Power and Plenty. Madison: University of Wisconsin Press.

Katzenstein, P. J., ED. (1996) The Culture of National Security. New York: Columbia University Press.

Keohane, R. O. (1984) After Hegemony. Princeton: Princeton University Press.

Keohane, R. O., And L. Martin (1999) "Institutional Theory as a Research Program." Paper prepared for the Annual Meeting of the American Political Science Association, Atlanta.

Keohane, R. O., And H. Milner, Eds. (1996) Internationalization and Domestic Politics. New York: Cambridge University Press.

King, G., R. O. Keohane, and S. Verba (1994) Designing Social Inquiry. Princeton: Princeton University Press.

Knight, J. (1992) Institutions and Social Conflict. New York: Cambridge University Press.

Krasner, S. (1983) "Structural Causes and Regime Consequences: Regimes as Intervening Variables." In International Regimes, edited by S. Krasner, pp. 1-21. Ithaca: Cornell University Press.

Krasner, S. (1991) Global Communications and National Power: Life on the Pareto Frontier. World Politics 43:336-366.

Kratochwil, F. V., and J. G. Ruggie (1986) International Organization: A State of the Art on an Art of the State. International Organization 40:753-775.

La Repubblica (1997) Ma I governatori scelgono il silenzio [But the Governors Chose Silence]. June 10 .

La Tribune (1997) L'accord de Münster est interprété différemment des deux côtés du Rhin [The Münster Agreement Is Interpreted in Different Ways on the Two Sides of the Rhine]. Oct. 16. 
Lawson, N. (1993) The View From No. 11. London: Doubleday.

Le Monde (1988) M. Chirac annonce qu'il prendra des initiatives dans le domaine monétaire [Mr. Chirac Announces He Will Take Initiatives in the Area of Monetary Policy]. Jan. 9, 24.

LEs ECHOS (1997) Euro: Français et Allemands rapprochent leur projet [Euro: France and Germany Bring Their Project Closer]. March 13, 1.

MacDonald, M. (1988) Time Said Right to Consider European Central Bank. Reuters Money Report, Jan. 14.

Marsh, D. (1988) Bonn Sees Monetary Union as a Distant Goal. Financial Times, Jan. 25.

Marsh, D. (1992) The Most Powerful Bank: Inside Germany's Bundesbank. New York: Random House.

McNamara, K. R. (1993) "Common Markets, Uncommon Currencies: Systems Effects and the European Community." In Coping with Complexity in the International System, edited by J. Snyder and R. Jervis, pp. 303-327. Boulder, CO: Westview.

McNamara, K. R. (1998) The Currency of Ideas. Ithaca: Cornell University Press.

Milner, H. (1997) Interests, Institutions, and Information. Princeton: Princeton University Press.

Moravcsik, A. (1997) Taking Preferences Seriously: A Liberal Theory of International Politics. International Organization 51:513-553.

Moravcsik, A. (1998) The Choice for Europe: Social Purpose and State Power from Messina to Maastricht. Ithaca: Cornell University Press.

Nölling, W. (1993) Monetary Policy in Europe after Maastricht. New York: St. Martin's Press.

Norman, P. (1997) France under Pressure to Clarify EMU Stance. Financial Times, June 11.

OAtley, T. H. (1997) Monetary Politics: Exchange Rate Cooperation in the European Union. Ann Arbor: University of Michigan Press.

Owen, R. (1997) Rome to Seek Allies for EMU Delay. Times, June 3.

Oye, K., ED. (1986) Cooperation under Anarchy. Princeton: Princeton University Press.

Papitto, F. (1997) "Accordo fatto" e l'Euro è salvo [“Agreement Reached" and the Euro Is Saved]. $L a$ Repubblica, June 17.

PeEL, Q. (1985) EEC States Square off over Monetary Plan. Financial Times, Dec. 3.

Peel, Q. (1987) EEC to Discuss French Plans on Currency Levels. Financial Times, Feb. 12.

Peel, Q., And P. Stephens (1987) EC Finance Ministers Agree to Boost EMS. Financial Times, Sept. 14.

PöHL, K. O. (1988) Statement on European Monetary Unification. Frankfurt: Deutsche Bundesbank, 5 May.

Price, R. (1998) Reversing the Gun Sights: Transnational Civil Society Targets Land Mines. International Organization 52:613-644.

Putnam, R. D. 1988. Diplomacy and Domestic Politics: The Logic of Two-Level Games. International Organization 42:427-460.

Renard, F. (1987) M. Balladur veut accélérer la construction de l'Europe monétaire [Mr. Balladur Wants to Accelerate European Monetary Integration]. Le Monde, Jan. 8.

Reuters. (1988) Stoltenberg Repeats Euro Central Bank Long-Term Goal. March 17.

Risse, T., D. Engelmann-Martin, H.-J. Knopf, and K. Roscher (1999) To Euro or Not to Euro? The EMU and Identity Politics in the European Union. European Journal of International Relations 5:147-187.

Rogowski, R. (1989) Commerce and Coalitions. Princeton: Princeton University Press.

Rogowski, R. (1999) "Institutions as Constraints on Strategic Choice." In Strategic Choice and International Relations, edited by D. A. Lake and R. Powell, pp. 115-136. Princeton: Princeton University Press.

Sachs, J., And C. Wyplosz (1986) The Economic Consequences of President Mitterrand. Economic Policy 2:262-322.

Sandholtz, W. (1993) Choosing Union: Monetary Politics and Maastricht. International Organization 47:1-39.

Stephens, P. (1982) [Untitled article] Reuters North European Service, 15 March.

Thatcher, M. (1993) The Downing Street Years. London: HarperCollins.

Ungerer, H. (1997) A Concise History of European Monetary Integration. London: Quorum.

Walsh, J. (2000) European Monetary Integration and Domestic Politics. Boulder, CO: Lynne Rienner.

Whelan, R. (1989) Delors Briefs French on EC Monetary Progress. Reuters, April 14.

Wendt, A. (1994) Collective Identity Formation and the International State. American Political Science Review 88:384-396.

Wyles, J. (1982) German Opposition Block to EMS Plan. Financial Times, March 15.

Wyplosz, C. (1989) Asymmetry in the ERM: Intentional or Systemic? European Economic Review 33:310-320.

Zysman, J. (1983) Governments, Markets, and Growth. Ithaca: Cornell University Press. 